\title{
A Case Study on Developing Students' Leadership Skills via Team Work Activities
}

\author{
Wenjie Chen \\ Department of Humanities, Shanghai Art \& Design Academy, Shanghai, China \\ Email:87149872@qq.com
}

How to cite this paper: Chen, W.J. (2019) A Case Study on Developing Students' Leadership Skills via Team Work Activities. Open Journal of Social Sciences, 7, 414-425. https://doi.org/10.4236/jss.2019.710036

Received: October 18, 2019 Accepted: October 28, 2019 Published: October 31, 2019

\begin{abstract}
This paper aims to explore how the students' leadership skills would be developed through team work activities in classes. As the definition of leadership is diverse and elusive, it is hard to evaluate whether the leadership skills of the students have been improved getting involved in team work. So, by extracting the core skills of leadership commonly recognized by both the academic and the business world, questionnaires and interviews are designed and made among two groups of students: teacher-students and vocational college students. Based on the data gathered, it's agreed that leadership can be cultivated through participating in team work teaching activities in classes.
\end{abstract}

\section{Keywords}

Leadership Skills, Team Work Activities, Teaching

\section{Introduction}

In 1980s, the concept of leadership expanded from business world to the fields of education, governance etc. Starting from early 1990s, the college students' leadership development have been expanding quickly. Leadership is now recognized to be the second most significant factor influencing school and pupil outcomes, after classroom practice [1]. "Teaching students about leadership and their development as leaders is becoming increasingly more important to colleges and universities across the country" [2]. Weng points out that youth is a crucial period for the development of leadership [3]. Thus, programs including undergraduate leadership programs, leadership certificate programs, and even more co-curricular leadership programs are offered to the students and the emerging young leaders in society. Although some traits and abilities are necessary for great leaders, now people would commonly agree that leadership skills 
can be taught and learned through practice over time [4].

\section{Design of Case Study}

\subsection{Terms to Be Defined}

A leader, as Carwright [5] defines, is "The person, selected or emergent, who moves others in the direction of goals that are clearly fixed as a vision in his or her mind and uses those others to achieve the desired end state". The leader bears the responsibility of leading or directing others to fulfil the goal which is also part of his own vision. Even if leaders might have some of the widely accepted merits, such as wide vision, commitment to goals, tenacity, good communications, and empathy etc., they are still humans.

However, the definition of leadership has always been elusive. Stogdill [6] (1974:259) states that "There are almost as many definitions of leadership as there are persons who have attempted to define the concept." When define leadership, people tend to put leadership and management together and make comparisons. Although part of their meanings overlaps, the distinctions of their definitions and roles are still obvious. Kotter (1991) states that management deals with "complexity" while leadership focuses on "change" [7]. They complement one another. Cuban gives the same opinion: Leadership is with change, and management with the maintenance of activities [8]. Dealing with complexity and dealing with change lead to different activities of management and leadership. Besides all these differences, most researchers agree that leadership above all is to create the vision of an organization [9]. But a fact need to be noticed: When "vision" was first introduced into China, it was hard to find its Chinese equivalent. So people coined a Chinese name "Yuanjing", which literally means the beautiful aim one wishes to reach in the future. As Chinese are more familiar with "goal", "aim", or "result" than with "vision", this may explain that vision might be the last skill to be chosen by Chinese when talking about the skills of leadership.

\subsection{The Core Skills of Leadership}

Owing to the elusiveness of the definition of leadership, to ask the students directly whether their leadership has been improved after taking courses of leadership will be elusive as well. So, I decide to reverse the causals and results: to use the commonly agreed core skills of leadership that one would pick up or improve after getting involved in team work activities in classes to measure whether his or her leadership has been improved. Ryan uses competency framework to "assess and develop the leadership behavior". "Competencies are, very simply, the behaviors, skills, and attributes that need to be demonstrated in order to gain high performance by any given group of managers" [10]. Ryan lists the following qualities for companies to seek managers: "team working, communication skills, people management, customer focus, results orientation, problem solving, planning and organizing", and plus "innovation, external market focus, leadership, 
and strategic thinking" [10]. All managers should meet the first seven items while the senior ones reach the last four more. In their study of Effective Leadership in the Early Years Sector (ELEYS), Siraj-Blatchford and Manni intent to explore the effectiveness of the educational leadership in the early years by studying the existing literature and studies, and what patterns of leadership can be identified in the sample of effective settings of Researching Effective Pedagogy in the Early Years (REPEY) [11]. Then they list the following "categories of effective leadership practice" of the ELEYS project which are valuable in leadership training:

- Identifying and articulating a collective vision

- Ensuring shared understandings, meanings and goals

- Effective communication

- Encouraging reflection

- Monitoring and assessing practice

- Commitment to ongoing, professional development

- Distributed leadership

- Building a learning community and team culture

- Encouraging and facilitating parent and community partnerships

- Leading and managing: striking the balance.

(Siraj-Blatchford, I. and Manni, L., 2012:12)

By analyzing and comparing the 2-day courses on leadership training which are offered by 6 management training agencies in the UK and the US, I find that these following word(s) appear in the courses with high frequency: team/ team building, motivation/ motive/ inspire/ influence, communication/ conversation, leadership, management, learning, grow/ strength, relationship, decision making, delegation, problem solving, coaching, self-development, risk taking and so on.

Extracting the key words from the above mentioned studies, I make a list of core skills of leadership that are both agreed by the academic and the industrial world: 1) vision; 2) team working; 3) communication; 4) problem solving; 5) learning; 6) motivation; and 7) managing.

These core skills of leadership convey several implications: 1) They can be developed through effective and practical courses and exercises; 2) Other than senior leaders, everyone can possess these skills; and 3) with these skills, effective and successful team can be built.

\subsection{Teamwork Activities in Classes}

Teaching activities in classes are important tools for teachers to organize their teaching, to facilitate the students to acquire knowledge, and to instill the students with some skills etc. In China, growing up in the culture of respecting the teachers and elders, the students are not encouraged to interrupt the teachers in classes without permission. Thus the students have got used to keeping silent, listening to the teacher, taking notes, and doing exercises individually in classes. 
So, teamwork spirit is what the students need to be cultivated most in school. Yet studies also show that students like to interact with their teachers and peers in classes. Based on a study, Xian and Sun found that teachers and students in English classes have different views on teaching activities [12]. Teachers prefer the traditional teacher-centered way of teaching to the interactive methods while the students like interactions with others. Study also shows that the effectiveness of group work can be influenced by the teachers' roles in group work, the topics chosen, the cooperative relationship among group members, and the appropriate length of time for group work. To make group work functions well in classes, the teacher should also help the individual group with some communicative strategies and relevant knowledge in advance. Cooperation among group members should be encouraged in particular [13].

In the study, the team work activities in classes refer to the teaching activities involved in by two or more students in the form of group discussion, seminar, group debate, group presentation etc. Team work activities and group work activities may be used alternatively in this paper.

\subsection{Design of the Case Study}

1) Samples to be tested

In teaching case study, it's important to define clearly the unit of analysis and description of the sample [14]. The sample in this study consists of 47 students in two types: 20 of which are teacher-students from 10 Shanghai-based vocational colleges who are sent by the Shanghai Education Commission in two Cohorts (I was a student in Cohort 2.) to study the program of MA Education Leadership in the University of Hertfordshire (UH); and 27 of which are vocational college students from a TasTAFE program of logistics jointly run by Shanghai Bangde Vocational College and TasTAFE. The teacher-students of both Cohorts have studied in the UH for more than half a year. They are chosen as part of the sample because they meet the requirements in two ways: a) They are students of $\mathrm{UH}$, and teachers or administrators of their own college; b) They are studying in an English environment with experienced tutors. Among these teacher-students, 4 are men (20\%), and 16 are women (80\%). As to the 27 college students, they have classes delivered by an international teaching faculty, who use English and more diversified teaching activities in their classes. $63 \%$ of the college students are boys and $37 \%$ are girls.

2) Design and test the questions for interviews

Cohen et al. [15] point out that interview may serve three purposes: obtaining the first-hand information from the interviewees, testing hypotheses or propose new ones; and working together with other data collecting methods. In order to fulfill these three tasks, I interviewed 10 teacher-students in Britain and Shanghai respectively. With the one in $\mathrm{UH}$, first, I want to know whether their colleges have conducted any kinds of programs of leadership development for the vocational students. Second, I intend to evaluate to what extent these teach- 
er-students have understood the concept of leadership after 5 months of study in $\mathrm{UH}$. With the second interview conducted at nearly the end of the program, I mainly focus on how much these teacher-students have learned from the courses, the tutors, and the teaching activities in their classes. What's more, I also want to understand how they have applied the learned skills to their work. Then I will make comparisons with the findings I get. As to the form of the interview, I will use the semi-structured one. With revised reference questions, I have successfully conducted two interviews with 10 teacher-students from Cohort 2 and one interview with 6 college students from TasTAFE logistics program.

3) The design and pilot of the questionnaire

The purpose of my questionnaire is to know to what extend the team work activities in classes could help the two different types of students develop their leadership skills. There are some points I must be very careful with when I design the questionnaires. First, the questions shouldn't be misunderstood by the teacher-students as a way to judge the tutors' teaching performance. Second, as the subjects are from different background, at least 2 types of questionnaires should be designed. When the questionnaire is ready, I tested it with two of my classmates, who gave me some suggestions. Thus, the reliability, validity and practicability of the questionnaire are secured.

By using the method of questionnaire, together with interview and observation, I hope to find out whether the students' leadership skills have been improved or not. The data will help me evaluate the effectiveness of the team work teaching activities, and hopefully, help the teachers improve their way of teaching. That's also an important reason why I choose case study as my methodology.

\section{Data Analysis and Findings}

\subsection{Background Information Analysis}

Of the 53 questionnaires sent out via email and printed paper, 47 were returned, a return rate of $88.7 \%$. Responses from these 47 students have been analyzed statistically.

Background information shows that among the 20 teacher-students, 6 are course teachers (30\%), 5 students' consolers (25\%), 4 administrators (20\%), 2 middle managers (10\%), and 4 deans (20\%). Before studying in the UK, only 6 of the 20 teacher-students have taken short-term courses offered by their colleges aiming at improving their leadership skills. When being asked the effect of the training, 5 of them (83\%) thought that their skills of leadership had been slightly (4 people) or greatly improved ( 1 people), and $1(17 \%)$ thought that it had no effect at all. No matter whether they have got trained or not, they unanimously agreed that leadership would be helpful for their future career development. Of the 20 teacher-students, $45 \%$ of them thought that leadership was made, and $55 \%$ agreed that both nature and training make great leaders. 
For the 27 freshmen, only $22 \%$ acknowledged that they had attended classes focused on leadership training. They either listened to lectures (17\%), attended outward bound training (66\%), or involved in voluntary work (17\%). Compared with the teacher-students, the students received their training mainly through outward bound training and voluntary work. As to the effect of their training, $33 \%$ of the trained students thought that the program was very useful in improving their leadership, while more students (67\%) confessed that it had little or no effect at all. Considering the vagueness of the concept of "lingdaoli" (leadership in English), I was surprised to find that the number (23) is so high of the students who haven't got any forms of leadership training think that leadership will be beneficial to their career development. Within these college students, $74 \%$ agree that one's leadership ability is a combination of nature and training. Compared with $44 \%$ from the teacher-students, only $22 \%$ college students thought that leadership can be developed. After taking the courses on leadership, more teacher-students think that leadership can be made.

\subsection{The Core Skills of Leadership Agreed by the Students}

When asked of the reason to take the MA program, over half (55\%) of the teacher-students choose "to improve my English", 35\% wanted to improve their skills of management. Only $10 \%$ said that they were just sent by the schools, which can only be interpreted as "They have no idea of why they take the program". Actually, as a teacher-student of Cohort 2, I found that even after attending classes in $\mathrm{UH}$ for a long time, all the students have no idea of the full name of the program and why leadership was so important in the program. One of the main reasons is that the students were confused with "management" and "leadership". The ambiguousness of the term leadership explains why the students are asked to choose the core skills of leadership listed in the questionnaire instead of answering the question like: What is the leadership?

In the two questionnaires, 9 skills of leadership were listed with one open choice. The interviewees were asked to make more than one choice. The core skills of leadership and the choices made are as follows (See Table 1 and Table 2):

Comparing the statistics, we can see the differences between the two types of students. The teacher-students have been studying the MA Education and Leadership courses for more than a year. No matter what their initial idea of leadership was, now they have a better understanding of what leadership is and

Table 1. Core skills of leadership chosen by the teacher-students.

\begin{tabular}{|c|c|c|c|c|c|c|c|c|c|c|}
\hline & 1 & 2 & 3 & 4 & 5 & 6 & 7 & 8 & 9 & 10 \\
\hline $\begin{array}{l}\text { Core Skills of } \\
\text { Leadership }\end{array}$ & $\begin{array}{l}\text { problem- } \\
\text { solving }\end{array}$ & communication & $\begin{array}{l}\text { motiving } \\
\text { others }\end{array}$ & $\begin{array}{l}\text { team } \\
\text { work }\end{array}$ & managing & self-confidence & $\begin{array}{c}\text { learning } \\
\text { ability }\end{array}$ & $\begin{array}{c}\text { Public } \\
\text { speaking }\end{array}$ & $\begin{array}{l}\text { Making } \\
\text { visions }\end{array}$ & $\begin{array}{c}\text { other choices } \\
\text { (EQ) }\end{array}$ \\
\hline Times & 18 & 17 & 17 & 16 & 16 & 13 & 11 & 10 & 8 & 1 \\
\hline$\%$ & $90 \%$ & $85 \%$ & $85 \%$ & $80 \%$ & $85 \%$ & $65 \%$ & $55 \%$ & $50 \%$ & $40 \%$ & $5 \%$ \\
\hline
\end{tabular}


Table 2. Core skills of leadership chosen by the college students.

\begin{tabular}{ccccccccccc}
\hline & 1 & 2 & 3 & 4 & 5 & 6 & 7 & 8 & 9 & 10 \\
\hline $\begin{array}{c}\text { Core-Skills of } \\
\text { Leadership }\end{array}$ & management & self-confidence & communication & $\begin{array}{c}\text { Problem } \\
\text { solving }\end{array}$ & $\begin{array}{c}\text { Team } \\
\text { work }\end{array}$ & $\begin{array}{c}\text { Motivating } \\
\text { others }\end{array}$ & $\begin{array}{c}\text { Public } \\
\text { speaking }\end{array}$ & $\begin{array}{c}\text { Learning } \\
\text { ability }\end{array}$ & $\begin{array}{c}\text { Making } \\
\text { visions }\end{array}$ & $\begin{array}{c}\text { other } \\
\text { choices }\end{array}$ \\
\hline $\begin{array}{c}\text { Times } \\
\%\end{array}$ & 18 & 17 & 17 & 16 & 16 & 13 & 11 & 10 & 8 & 0 \\
\hline
\end{tabular}

what they need most in their work. They rank problem-solving, communication, motivating others, team work, and management as the first 5 core skills of leadership.

Among the college students, $26 \%$ are student leaders, while $74 \%$ have no position. The ratio between those who have taken leadership development courses and those who haven't is 6:21. According to their choices, the college students rank management, self-confidence, communication, problem-solving, and team work as the first 5 key skills. As people always take it for granted that to lead is to manage, the students' first choice just proves it. Because "making visions" is a new concept in China, no wonder that it is listed as the least important core skill of leadership by both the experienced teachers and college students. The students gave no extra choice while one teacher-student added EQ as a key skill of leadership.

\subsection{Teaching Activities in Classroom}

When designing the question concerning the teaching activities the teacher-students like most, I gave them 2 more choices: seminar and debate, which are used frequently by their tutors in the UH classrooms. I did this because even the English level of the vocational students is a little better than that of other students, seminar and debate are rarely used among them. Here are their choices (See Table 3 and Table 4).

Both group of students chose "group discussion" and "presentation" as their most favored teaching activities in classes. The teacher-students also think that "seminar" and "debate" are useful in classes. A very interesting phenomenon is that more college students (44\%) like self-study than the teacher-students do (25\%).

In China, teachers, as well as the students, have been used to the style of "listening to the teachers passively" in classes ever since they started their schooling. Taken seminar as an example. This form of activity can be found in some academic or business meetings in China, but very rarely in classes at undergraduate or vocational college level. When the students are asked to organize seminars and maybe take a lead, this is totally a new and exciting experience for them. But once they accept the challenge, they will like it. Presentation is another activity popular among both the groups. Making a presentation in front of the class and being "tortured" by tough questions from tutors and classmates, the students will get their points clearer with wetting palms. Maybe some students would 
Table 3. Classroom teaching activities liked by teacher-students.

\begin{tabular}{ccccccc}
\hline & 1 & 2 & 3 & 4 & 5 & 6 \\
\hline choice & seminars & presentation & group discussion & debate & self-study & other means (Open) \\
\hline Times & 14 & 12 & 15 & 8 & 5 & 1 (coaching) \\
$\%$ & $70 \%$ & $60 \%$ & $75 \%$ & $40 \%$ & $25 \%$ & $5 \%$ \\
\hline
\end{tabular}

Table 4. Classroom teaching activities liked by college students.

\begin{tabular}{ccccc}
\hline & 1 & 2 & 3 & 4 \\
\hline choice & presentation & group discussion & self-study & other means (Open) \\
\hline Times & 15 & 21 & 12 & 0 \\
$\%$ & $56 \%$ & $78 \%$ & $44 \%$ & 0 \\
\hline
\end{tabular}

think that learning is an individual matter and they prefer to study by themselves, yet a change in teaching style will give them a totally fresh experience. Although it takes them a little while to get used to group work teaching activities in classes, the teacher students like them more than self-study. The ratio of their choice says this clearly.

Research indicates that in the organizational world, if a team does not work, the reasons mainly lie in factors such as confused goals, unresolved roles, lack of trust, unwillingness to change, the wrong tools, or bad leadership. With either western teachers or Chinese teachers using instructions in a foreign language, their priority in organizing team activities in classes is to make sure that the students understand the task. Otherwise, the whole group will get lost until they know what they are asked to do.

\subsection{Improvement Made on the Abilities/Skills of Students after Taking Part in the Teaching Activities}

After taking active part in team work teaching activities in classes for a year, the teacher-students think that they have made the following improvements with their abilities/skills, all of which are the key skills of leadership (See Table 5).

The teacher-students think that their abilities/skills such as team work, communication, public-speaking, and problem-solving have been improved greatly. One thinks that his/her teaching ability has been sharped. In the UH classes, the tutors always ask the students to sit and work in groups of 4 or 6 . To finish the work assigned by the tutor, the students have to cooperate and communicate with each other. They are asked to think creatively and critically. As a participant, I can see the changes my classmates made when they said each time after the discussion: "Now I am clear what I am going to do!" By and by, their ability in problem-solving has been honed. As these are all key skills of leadership, no wonder when they were asked whether their management skills either in administration or in teaching have been improved after getting involved in team work teaching activities in classes, half of them think they had, and the other half 
Table 5. Improvement made on the abilities/skills of teacher-students.

\begin{tabular}{cccccc}
\hline & 1 & 2 & 3 & 4 & 5 \\
\hline Abilities/skills & team work & communication & public-speaking & problem-solving & others (Open) \\
\hline Times & 13 & 13 & 13 & 11 & 1 (teaching ability) \\
$\%$ & $65 \%$ & $65 \%$ & $65 \%$ & $55 \%$ & $5 \%$ \\
\hline
\end{tabular}

think they had to some degree. When being asked what they learned most from this program, $85 \%$ of the teacher-students thought that their English had been improved, and $65 \%$ chose management ability, and all the faculties chose teaching ability.

As to the college students, their answers to the question "What abilities /skills of yours have been improved by getting involved in team work teaching activities" are as follows: (See Table 6)

The college students are from a Sino-Australia logistics program. Their teachers are either westerners or Chinese with overseas study experiences. The teaching activities used by these teachers are more diversified than those used by the Chinese teachers without studying abroad. With this question, the students chose team work, problem-solving, and communication as the most important skills they acquired from the teaching activities in classes.

Comparing the students' choices with those of the teachers, we can see that the only difference is that problem-solving was ranked the second by the former, and the fourth by the latter. From the perspective of the students, problem-solving is more important than public speaking in participating those teaching activities. Based on my own experience, I will always have the students to solve a problem in groups. Students, especially the non-English majors in vocational colleges are usually not good at using English. To speak in English can be a big challenge for them. This might explain the sequence in importance with "problem-solving" and "public speaking" in the students' mind.

By analyzing these data, we can see that no matter what background they are from, with a small change in the teaching styles, the students can learn a lot in terms of their abilities and skills. Indirectly, their skills of leadership have or will be improved accordingly.

\section{Conclusions}

The world is changing fast. Greenwald [16] thought that we are living in a "micropreneurial age" and the students must equip themselves with the skills, knowledge, and qualities that leadership programs can cultivate: self-reliance, lifelong learning, creativity, problem-solving, and team-building skills, etc. We will not expect the students who have taken leadership programs to become leaders immediately, but "ideally they will have the skills to lead tomorrow's generation and to thrive in the new economy" [16].

The education and development of students as leaders has long served as a central purpose for institutions of higher education [17]. Many studies have 
Table 6. Improvement made on the abilities/skills of college students.

\begin{tabular}{cccccc}
\hline & 1 & 2 & 3 & 4 & 5 \\
\hline Abilities/skills & team work & problem-solving & communication & public-speaking & others \\
\hline Times & 17 & 17 & 16 & 10 & 0 \\
$\%$ & $63 \%$ & $63 \%$ & $59 \%$ & $37 \%$ & 0 \\
\hline
\end{tabular}

proved that students can and do increase their leadership skills during their college years. Although my research is based on a small sample, it still reveals some values that deserved our attention:

- Leadership skills can be cultivated through participating in team work teaching activities. No matter who the participants are - teacher-students or college students, their skills or abilities can be improved, which in turn improve their leadership ability.

- Among all the team work or group work teaching activities, group discussion, seminar, presentation, group discussion, debate are all favored by the students. Once they like the teaching activities, students tend to enjoy participating in it. The learning effect, from the perspective of skill improvement and academic enhancement, will be doubled.

- Team work teaching activities can be used to build the team spirit of the students. This is what the Chinese students need most. No matter which group of the students, they all think that their team spirit has been improved.

- The skills learned in classroom are transferable. The interviews showed that many teacher-students are now using some teaching activities their English tutors used in classes. And for other non-course teachers, their way of working unperceivably changed when they came back from Britain.

With the participant of the course teachers, classes, other than English classes, can be used to improve the students' leadership skills. But to make it works, first, the teachers should be trained to know what leadership is and understand the importance of leadership for the students' future career development. Second, the teachers need to know the core values of leadership and know very well how to integrate them into their teaching activities in classes. This needs time and technique.

The school should invite some great leaders in their own fields to talk with the college students about leadership. The power of model is greater. What is more, the students should take community work and voluntary work. Compared with the college students, the teacher-students learned more from the classroom teaching activities than the college students. The advantage of the teacher-students is that they can put the skills to use in their work immediately after they come back to China.

In order to make this model of improving the students' skills of leadership work well, some problems need to be solved:

1) With team work activities, the instructions must be understood clearly by the students. Otherwise, time and effects will all be discounted. With western 
teachers, make sure that each group know what they are going to do.

2) The teacher, either western or Chinese, need to spend more time with the students. Data collected from the interviews show that the more time you spend with the students, the more effective the result will be.

3) The size of the class shouldn't be too big. 20 to 30 will be perfect. With larger classes, the teacher will be very difficult to organize the group work activities.

What I need to improve with this project in the future is to have a larger sample. With questionnaire, interviews etc., I could have a holistic picture of how leadership skills will be improved through team work teaching activities. Benson \& Saito [18] states: "increases in leadership development in turn enhance the self-efficacy, civic engagement, character development, academic performance, and personal development of students".

As an English teacher and director of the Department of Humanities in a vocational college, I have rich experience in teaching and leading, especially after my graduation from the University of Hertfordshire. Lomax [19] states: "I want educators' voices to be heard and I want them to share their values and persuade others about the significance of their work." I want my voice to be heard by others.

\section{Conflicts of Interest}

The author declares no conflicts of interest regarding the publication of this paper.

\section{References}

[1] Leithwood, K., Day, C., Sammons, P., Harris, A. and Hopkins, D. (2006) Seven Strong Claims about Successful School Leadership. Department for Education and Skills, London.

[2] Cress, C.M., Astin, H.S., Zimmerman-Oster, K. and Burkhardt, J.C. (2001) Development Outcomes of College Students' Involvement in Leadership Activities'. Journal of Student Development, 42, 15-25.

[3] Weng, W.Y. (2011) The Status Quo and Development Methods of College Students' Leadership. Contemporary Youth Research, 3, 21-26.

[4] Nahavandi, A. (2006) Teaching Leadership to First-Year Student in a Learning Community. Journal of Leadership Education, 5. https://doi.org/10.12806/V5/I2/AB2

[5] Cartwright, R. (2002) Mastering Team Leadership. Palgrave Macmillan, New York. https://doi.org/10.1007/978-1-349-91440-1

[6] Stogdill, R. (1974) Handbook of Leadership: A Survey of Theory and Research. Free Press, New York.

[7] Kotter, J.P. (1991) What Leaders Really Do. In: Harvard Business Review (eds.) Managers as Leaders, Harvard Business School Press, Boston, 3-12.

[8] Cuban, L. (1988) The Managerial Imperative and the Practice of Leadership in Schools. State University of New York Press, Albany, NY.

[9] Day, D.V. (2001) Leadership Development: A Review in Context. Leadership Quar- 
terly, 11, 581-613. https://doi.org/10.1016/S1048-9843(00)00061-8

[10] Ryan, R. (2008) Leadership Development a guide for HR and Training Professionals. Elsevier, Oxford.

[11] Siraj-Blatchford, I. and Manni, L. (2012) Effective Leadership in the Early Years Sector: The ELEYS Study. Institute of Education Press, London.

[12] Xian, X.B. and Sun, X.L. (2007) Investigation and Analysis on Teaching Activities in English Classes between Teachers and Students. Journal of Xi an International Studies University, 15, 91-93.

[13] Deng, X.E. and Zheng, X.M. (2008) Study on the Effectiveness of Group Work in College English Classrooms. Computer-Assisted Foreign Language Education in China, 122, 41-46.

[14] Zucker, D.M. (2009) How to Do Case Study Research. School of Nursing Faculty Publication Series. Paper 2.

[15] Cohen, L., Manion, L. and Morrison, K. (2007) Research Methods in Education. 6th Edition, Routledge, London.

[16] Greenwald, R. (2010) Today's Students Need Leadership Training Like Never before. The Chronicle of Higher Education.

http://m.chronicle.com/article/Todays-Students-Need/125604/

[17] Astom, A.W. and Astin, H.S. (2000) Leadership Reconsidered: Engaging Higher Education in Social Change. W.K. Kellogg Foundation, Battle Creek.

[18] Benson, P. and Saito, R. (2000) The Scientific Foundations of Youth Development. Search Institute, Minneapolis. https://doi.org/10.1007/978-1-4615-1459-6 5

[19] Lomax, P. (2002) Action Research. In: Coleman, M. and Briggs, A., Eds., Research Methods in Educational Leadership and Management, Paul Chapman Publishing, London. 